\title{
A Glimpse at Ethology in Latin America
}

\author{
SPINELLI OLIVEIRA, E. ${ }^{1 *}$;CANTANO, L. M. R. ${ }^{1}$; BAPTISTA, T. ${ }^{2}$; BOERE, V. \\ FERRARI, H. R. ; FRANCESCOLI, G. ${ }^{5}$; JOSENS, R. ${ }^{6}$; KLEIN, W. ${ }^{7}$; MONTICELLI, P. F.; \\ WHITLOCK, K. ${ }^{9}$; SANTOS, W. F. ${ }^{10}$
}

The state of the art of Ethology in five Latin America countries is briefly presented here. The overall outlook regarding research laboratories and themes is promising: the community is numerous, active and there are topics addressing all aspects of animal behavior, especially in large countries like Brazil and Argentina. Ethology as an undergraduate discipline is generally a subcategory of Biology, being taught mainly at Zoology/ Psychology/ Ecology/ Agriculture Courses and at Medical Veterinary Schools, often as an eligible discipline. Ethology as a formal major Graduate Program is rare and mainly restricted to Brazil. Regular Ethology meetings are held in Argentina, Brazil and Uruguay. In Chile and Venezuela there is a small but very active community. Studies of animal behavior are often carried out in other areas than Biology, and there is a clear overlap of interest regarding the major topics of Ethology. Behavioral ecology, conservation, management and animal welfare are a priority in most countries, probably reflecting a general concern regarding endangered species and habitats of the continent. Here we present information aiming to create a network that will increase collaborations among researchers working within the ethological framework in Latin America. The IV Simpósio de Etologia na América Latina, entitled "Desarrollo de la Etología en Latinoamérica:¿ hacia un futuro regional ?" was held in November, 2013, as part of the XXXI Encontro Anual de Etologia (EAE), in São Paulo, SP, Brazil. The state of art of Animal Behavior in Argentina, Brazil, Chile, Uruguay and Venezuela were presented there and a set of six questions guided the presentations: 1) What are the main Ethology topics being studied in laboratories in your country? - 2) Are there undergraduate or graduate programs in the main universities? - 3) Is there an Animal Behavior Society? How interested is the community in establishing close ties among institutes or laboratories elsewhere in Latin America? - 4) Is there a site, a journal, a page on a social networking site for contact, communication and divulgation of original data? - 5) How active is the community regarding the wiliness to organize congresses, symposia, meetings, workshops, on-line courses regarding Ethology? - 6) Are there funding agencies to support exchange programs and research in Ethology? Additional data were collected from the last two EAE regarding researchers from Latin America that attended EAE meetings and a list of names and laboratories was compiled (see appendix). It should be emphasized that the compilation of information presented here is far from complete. It represents a brief overview of the current status of Ethology in only five Latin American countries, and therefore it should be updated continuously with new data from the countries treated here as well as supplemented with data from other countries. Such a constantly updated list would facilitate the creation of networks that should increase collaborations among researchers working within the ethological framework in Latin America.

Keywords: Ethology; network; animal behavior; Latin America.

1 Laboratório de Ecofisiologia e Comportamento de Roedores Silvestres (LECO), Departamento de Biologia, Faculdade de Filosofia, Ciências e Letras de Ribeirão Preto (FFGLRP), Universidade de São Paulo (USP), phone: (55)(16) 33153633, Av. Bandeirantes, 3900, 14040-901, Ribeirão Preto, SP, Brasil, (*Corresponding author)

2 Department of Physiology, Medical School, Los Andes University, Mérida, 5101-A, Venezuela

3 Departamento de Bioquímica e Biologia Molecular, Universidade Federal de Viçosa, 36570-000, Viçosa, MG, Brasil

4 Universidad Nacional de La Plata, Av 7 877, La Plata, Buenos Aires, Argentina

5 Facultad de Ciencias, Universidad de la República, Iguá 4225, Montevideo 11400, Uruguay

6 Instituto de Fisiología, Biología Molecular y Neurociencias, Facultad de Ciencias Exactas y Naturales, Universidad de Buenos Aires (UBA), Buenos Aires, Argentina

7 Laboratório de Morfofisiologia de Vertebrados, Departamento de Biologia, FFCLRP, USP, Av. Bandeirantes, 3900, 14040901, Ribeirão Preto, SP, Brasil

8 Laboratório de Etologia e Bioacústica (EBAC), Departamento de Psicologia, FFCLRP, USP, Av. Bandeirantes, 3900, 14040901, Ribeirão Preto, SP, Brasil

9 Centro Interdisciplinario de Neurociencia de Valparaíso (CINV). Universidad de Valparaíso, Avenida Gran Bretaña 1111, Valparaíso, Chile

${ }^{10}$ Laboratório de Neurobiologia e Peçonhas, Departamento de Biologia, FFCLRP, USP, phone: (55) (16) 33153657, Av. Bandeirantes, 3900, 14040-901, Ribeirão Preto, SP, Brasil 
Presentamos brevemente el estado de la Etología en cinco países de América Latina. En general, con respecto a la investigación en laboratorios y temas de estudio la situación es prometedora: la comunidad es numerosa, activa, y los temas abarcan todos los aspectos del comportamiento animal, especialmente en países grandes como Brasil y Argentina. La Etología como disciplina de grado, por lo general es una subcategoría de la Biología, siendo impartida principalmente en cursos de Zoología /Psicología/ Ecología/Agricultura, y en las facultades de Medicina Veterinaria frecuentemente como disciplina opcional. No es frecuente que la Etología sea un programa formal de Posgrado, lo cual está principalmente restringido a Brasil. Se realizan encuentros regulares de Etología en Argentina, Brasil y Uruguay. En Chile y Venezuela se encuentran comunidades pequeñas pero muy activas, ligadas a la Etología.

Los estudios de comportamiento animal se realizan frecuentemente en áreas distintas de la Biología, y hay una clara superposición de intereses respecto a los principales tópicos de la Etología. La ecología comportamental, la conservación, el manejo y el bienestar animal son prioridades en muchos países, lo que probablemente refleja una preocupación general respecto a las especies y hábitats amenazados en el continente.

Aquí presentamos un informe preliminar orientado a crear una red que aumente la colaboración entre los investigadores que trabajan en el marco de la Etología en América Latina. El IV Simposio de Etología de América Latina, titulado "Desarrollo de la Etología en Latinoamérica:¿hacia un futuro regional?” se realizó en Noviembre de 2013, como parte del XXXI Encontro Anual de Etologia (EAE), en São Paulo, SP, Brasil. Invitados de cinco países -Argentina, Brasil, Chile, Uruguay y Venezuela- presentaron información sobre el estado del arte del comportamiento animal en sus naciones y las presentaciones fueron guiadas por un cuestionario de seis preguntas: 1) ¿Cuáles son los principales temas de estudio y laboratorios de Etología en su país? - 2) ¿Hay programas de grado o posgrado en las principales universidades? - 3) ¿Hay una sociedad de Comportamiento Animal? ¿Qué tan interesada está la comunidad en establecer vínculos estrechos entre institutos o laboratorios en otros lugares de América Latina? - 4) ¿Hay un sitio de internet, una revista o un en una red social para contacto, comunicación y divulgación de datos originales? - 5) ¿Qué tan activa es la comunidad respecto a la organización de congresos, simposios, encuentros, talleres y cursos on-line referidos a Etología? - 6) ¿Hay agencias de financiamiento para sostener programas de intercambio e investigación en Etología? Adicionalmente se recolectaron datos de los últimos dos EAE concerniente a los investigadores en América Latina que asistieron a los mismos y se compiló una lista de nombres y laboratorios.

Palabras clave: Etología; red; comportamiento animal; América Latina.

\section{Main laboratories and topics of common interest}

In large countries like Argentina and Brazil there are different approaches to Ethology, such as Animal Cognition, Applied Ethology, Behavioral Ecology, Conservation \& Animal Welfare, Evolution of Behavior, Evolutionary Psychology/ Human Ethology, Neuroethology and Behavioral Physiology, which are well represented by many laboratories (Table 1, 2, 3 and appendix). There is a clear overlap of interests among all countries regarding the following topics: i) Animal Welfare and Applied Ethology, ii) Behavior Ecology mainly of insects, spiders, fish, bats, endemic rodents, birds and primates; iii) Communication and Sensory Ecology; iv) Social behavior of bees, and other insects, including agricultural pests and vectors of human diseases, and v) Neuroethology.

\section{Uruguay: laboratories and main topics}

In Uruguay there is a Sección Etología at the Instituto de Biología, linked to the Faculdad de Ciencias,
Universidad de la República Uruguaya (URU). The Laboratorio de Etología, Ecología y Evolución (EEE), and the Laboratorio de Ecología del Comportamiento (EG) are located at the Instituto de Investigaciones Biológicas Clemente Estable (IIBCE), of the "Ministerio de Educación y Cultura" (MEC) (Table 1).

1. The main topics at Sección Etología (URU) are: 1) Communication in derived vertebrates (Dr. G. Francescoli); 2) The role of sexual selection in population differentiation processes (Dra. B. Tassino); 3) Primate Behavior in captivity (MSc. S. Corte); 4) Applied Ethology regarding animal welfare (MSc S. Corte); 5) Social behavior of bees and bumblebees, (MSc. G. Invernizzi); 6) Ecoethology of subterranean endemic rodents (G. Izquierdo), 7). Reproductive behavior of annual fishes (Dra. B. Tassino); 8) Reproductive strategies of "lobos marinos" (Dra. B. Tassino) and 9) Communication and social behaviour in subterranean rodents (Dr. Gabriel Francescoli).

2. At the "Facultad de Ciencias" (URU) Ethology is also studied in other areas such as: I. 
Entomology: Control of insect pest in agroecosystems: the role played by spiders (Dra. C. Viera); II. Physiology: Behavioral physiology (Dra. A. Ferreira); III. Vertebrates: a) Interaction of pinnipedes and artisanal fishing (Dra. D. Szteren), b) Sexual selection of annual fish (Dr. M. Loureiro); IV. Systematics and Natural History of Vertebrates: a) The Biology of Anurans (Dr. R. Maneyro), b) The Biology of Reptiles (MSc. M. Meneghel); V. Neurosciences: Models of perception using electrolocation by electrical fish of weak discharge (Dr. L. Gómez).

3. The following projects are carried out at the Faculdad de Veterinaria (URU): I. Physiology (Dr. R. Ungerfeld): 1) Ovine sexual behavior; 2) Social hierarchy and its effect upon production and reproduction; 3) Reproductive biology of wild deer; 4) Weaning of beef cattle; - II. Animal Welfare Group, under the supervision of Dr. S. M. Huertas: a) Bovine transport: welfare aspects; b) Studies of social interaction of two horse groups in semi-natural enclosures.

4. At the Chemical Ecology Laboratory (URU), Dr. A. González and Dr. C. Rossini are responsible for the following lines of research: Insect behavior in relation to chemical communication and chemical characterization of semichemicals: a) the context of intraspecific communication (pheromones); b) the role of plant kairomones; and c) the role of allomones defenses.

5. The main focus at MEC/ IIBCE/ EEE is "Behavior, ecology and evolution of Neotropical spiders" (Dr. F. Costa) and the main research lines are: a) sexual behavior, sexual selection, reproductive strategies, and reproductive isolation; and b) social, parental, predatory, and territorial behavior. At MEC/ IIBCE/ EC the main research line is "Web construction and habitat selection" (Dr. C. Viera) and topics include: a) the evolution of sociality in spiders, and b) predatory and nest-building behaviors of spiders applied to pest management. At IIBC I. the line of research entitled "Neuromodulation of aggression in electrical fishes" is carried out under the supervision of Dr. A. C. Silva (Neurophysiology/ The neural basis of behavior).
Venezuela: laboratories and main research lines

In Venezuela researchers directly linked to Ethology can be found at the "Universidad de los Andes" (ULA), in Merida, at the "Universidad Simón Bolivar" (USB) and "Universidad Central de Venezuela" (UCV), both in Caracas (Table 1). The main lines of research are: a) sensory ecology of bats (olfaction) (Drs. M. Muñoz-Romo and P. Ramone); b) the distribution of Chagas' disease vector in cities of Venezuela, and the geometry of the vector's eggs (Rhodnius) (Dr. E. Aldana) at ULA; c) Behavioral ecology, conservation and management of terrestrial vertebrates with emphasis on capybaras (Hydrochoerus hydrochaeris) (Dr. E. Herrera), at USB; d) Termites, ants and cash crops (Dr. K. Jaffe), and e) sensorial ecology of frogs (Dr. Z. Tarano), at UCV.

\section{Ethology at the Graduate and Undergraduate level}

Ethology is taught as a discipline in undergraduate and graduate institutions of every country, but rarely as a major program (Table 1). An exception is the Graduate Program of Neurociências e Comportamento (NeC), at the Institute of Psychology, Universidade de São Paulo, Brazil, which offers Master and Doctoral Degrees in Neuroscience and Behavior, including Animal Behavior. Graduate programs of Biology, Ecology, Psychology, Zoology, Medical Veterinary and Medicine have laboratories where students can develop dissertations that focus on animal behavior topics. In general the scenario at the undergraduate level is similar. Ethology is offered as a discipline, often as elective, mainly as part of Courses of Biology, Psychology and Veterinary Medicine.

In Venezuela, Ethology is a course at the undergraduate level of the Licenciatura en Biología and there is not a formal Graduate Program. In Uruguay Ethology is part of what is called Licenciatura en Ciencias Biológicas and it is also possible to get a degree of Especialización en Etología.

These main disciplines in undergraduate programs in Uruguay are: 1. Introduction to Ethology, 2. Biosemiotics and Animal Communication, 3. Methods in Ethology, 4. Behavioral Ecology and 5. Concepts in animal welfare. At the Graduate level it is offered as a Master Degree in Biological Sciences (Zoology) and a Doctorate degree in Biological Sciences $(\mathrm{PhD})$, within the Programa de Desarollo de las 
Ciencias Básicas (PEDECIBA/ http://www.pedeciba. edu.uy/indice.php) (Table 1).

In Brazil the teaching of Ethology is unevenly distributed among the regions (Southeast> South> Northeast $>$ Central-West $=$ North $)$ and within undergraduate programs (Psychology $>$ Biology $>$ "Animal Science" $>$ Veterinary Medicine $>>$ Ecology $>$ Agronomy $=$ Engineering of production $=$ Aquaculture $=$ Oceanography $=$ Medicine $)$. A recent study revealed that in Brazil 26\% of the undergraduate programs in Veterinary Medicine present Ethology as a discipline (Borges et al, 2013).

In Argentina there are no Ethology graduate programs or specialization in Ethology. Nonetheless, animal behavior topics are addressed at the undergraduate and graduate level. Animal Welfare as a discipline is taught at Medical Veterinary Schools, and the Biology of Behavior is studied at Schools of Psychology and Schools of Biology. Tables 1, 3 and appendix summarize the main institutions, topics of undergraduate and graduate programs and the main lines of research carried out in this country.

\section{Societies, Congresses, Meetings and Workshops}

1. Societies of Ethology are found in Brazil and Chile and these are members of the International Council of Ethology (ICE), according to the ICE site (http://www.ethologycouncil.org/?page_ id=166) (Table 1). The "Asociación Argentina de Ciencias del Comportamiento" (AACC), founded in 1987, has Psychology as its main focus. AACG is member of the International Union of Psychological Sciences and it promotes biannual meetings in Argentina. The "XIV Reunión Nacional y III Encuentro Internacional De La Asociación Argentina de Ciencias del Comportamiento" was held at the Facultad de Psicologia, Universidad Nacional de Córdoba, in August 2013. In the same year a meeting entitled "COMPORTA 2013" was held in Mar del Plata, Argentina, focusing upon Animal Behavior. There are also societies for Neuroscience, Ecology, Chemical Ecology that promote their own regular meetings, in which animal behavior is a topic that is addressed. A similar fact occurs with specific societies for different taxa as for the study of mammals, herpetology, entomology, etc. Many of those societies and associations have also their own journal.

2. In Brazil the Sociedade Brasileira de Etologia (SBEt) promotes annual meetings (EAE), and since 2010 it has included the Latin America Symposium of Ethology. SBEt has also been responsible for the Revista de Etologia since 1998. There are many specific societies that include behavior as a topic, such as the Sociedade Brasileira de Primatologia (www.cbprimatologia), Sociedade Brasileira de Zootecnia (executiva@sbz.org.br),Sociedade Brasileira de Mastozoologia (sbmz.com.br), Sociedade Brasileira de Ictiologia (http://www.sbi.bio.br/), and so on. These societies regularly promote their own meetings.

3. In Uruguay, although small, the community is very active, participating in Congresses and Workshops. Since 2007 a biannual meeting fornadas Uruguayas de Comportamiento (JUCA) has been organized.

\section{Concluding remarks:}

The data presentation at the Symposium "Desarrollo de la Etología en Latino américa: ¿hacia un futuro regional?" was followed by a debate that included among others Dr. Martin Giurfa, representing Argentina, and Dr. Gabriel Ramos-Fernandez, from Mexico. The scenario that emerged is the clear potential for integration that exists among researchers of Ethology in Latin America. Research areas incorporate every major aspect of Ethology. There are laboratories willing to accept exchange students and financial support is available.

There is also a sound structure for education of Ethology in most countries. Nonetheless an aspect that should be emphasized is the fact that "Ethology" and "Animal Behavior" are embedded within other courses and programs at most universities, thus it is not identified by title, so it is often difficult to have access to information regarding course catalogs. A proposal that emerged from the discussion was to organize a future EAE in Argentina, as a step to break the institutional barriers that presently exist, thereby increasing integration and exchange of knowledge within Latin America. Another step is to increase the exchange of information through social media. In this respect SBEt has a site, which is willing to accept information regarding laboratories, including research areas, and educational programs of other countries in Latin America. 
Elisabeth Spinelli de Oliveira et al.

\section{References}

Borges, T. D., Sans, E. C. O., Braga, J. S., Machado, M. F., \& Molento, C. F. M. (2013). Ensino de bem-estar e dor animal em cursos de medicina veterinária no Brasil.
Arquivo Brasileiro de Medicina Veterinária e Zootecnia, 65(1), 29-36. Retrieved April 23, 2014, fromhttp://www. scielo.br/scielo.php?script=sci_arttext\&pid=S010209352013000100005\&lng=en\&tlng=pt. 10.1590/ S0102-09352013000100005. 


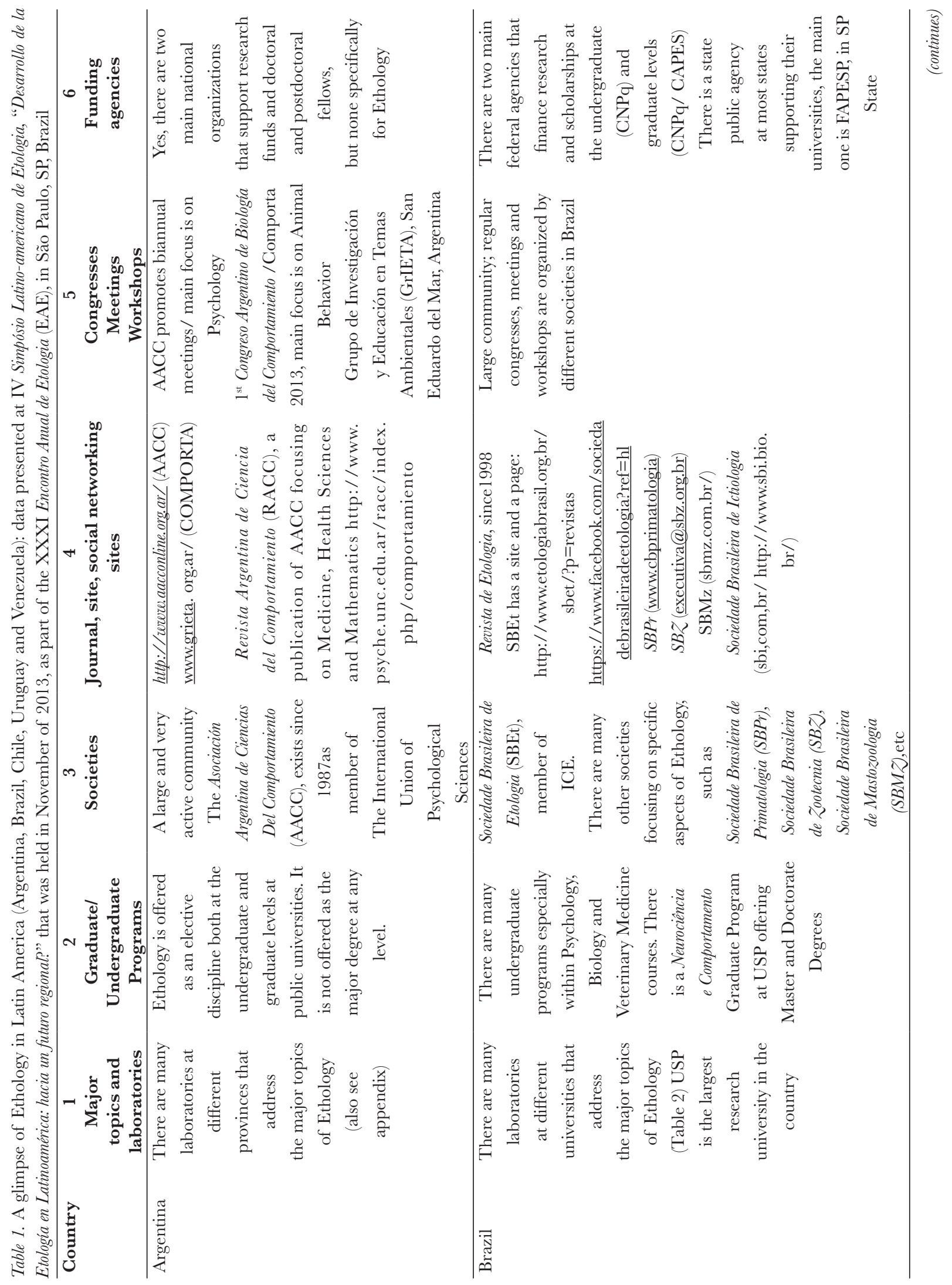




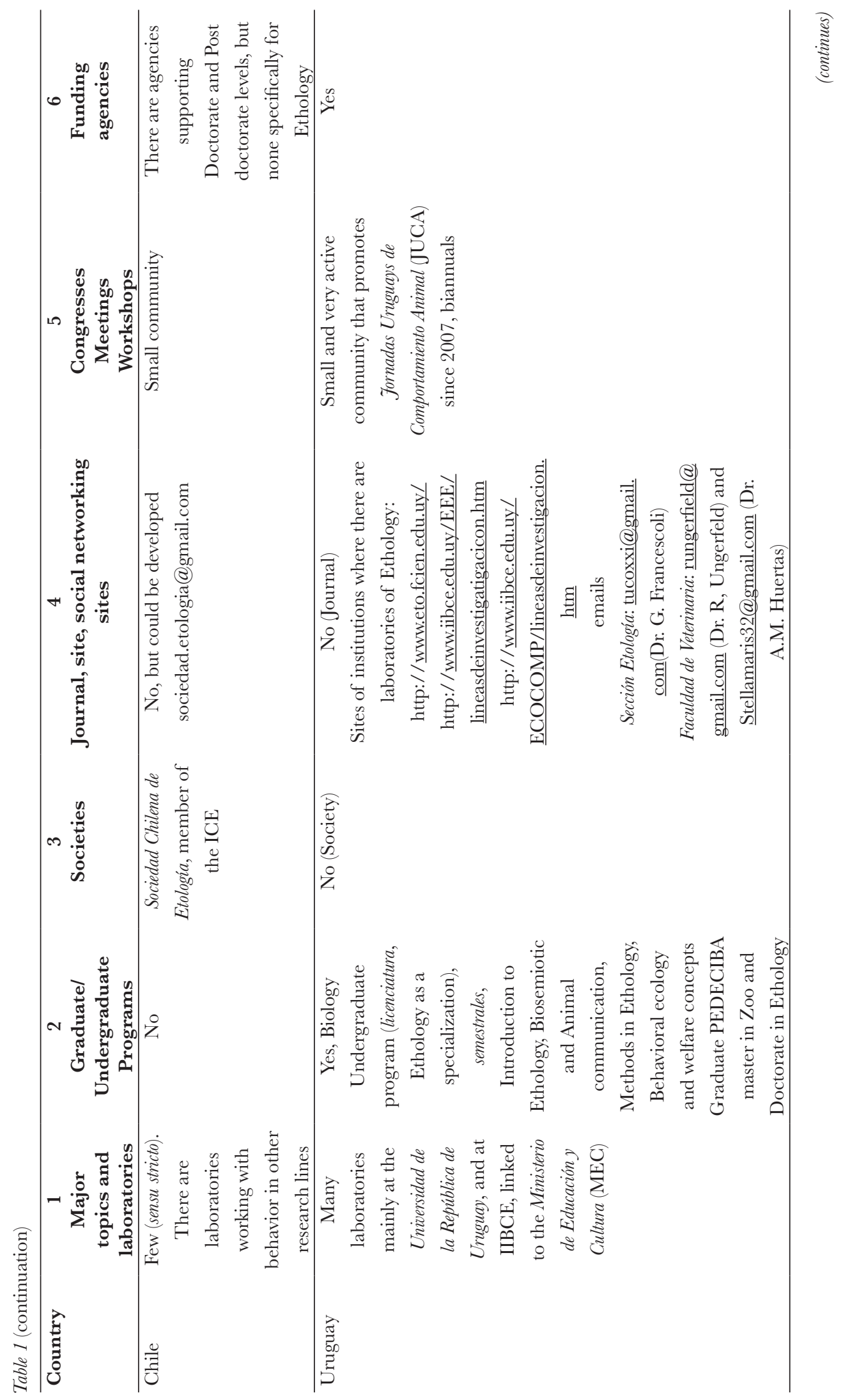


A Glimpse at Ethology in Latin America
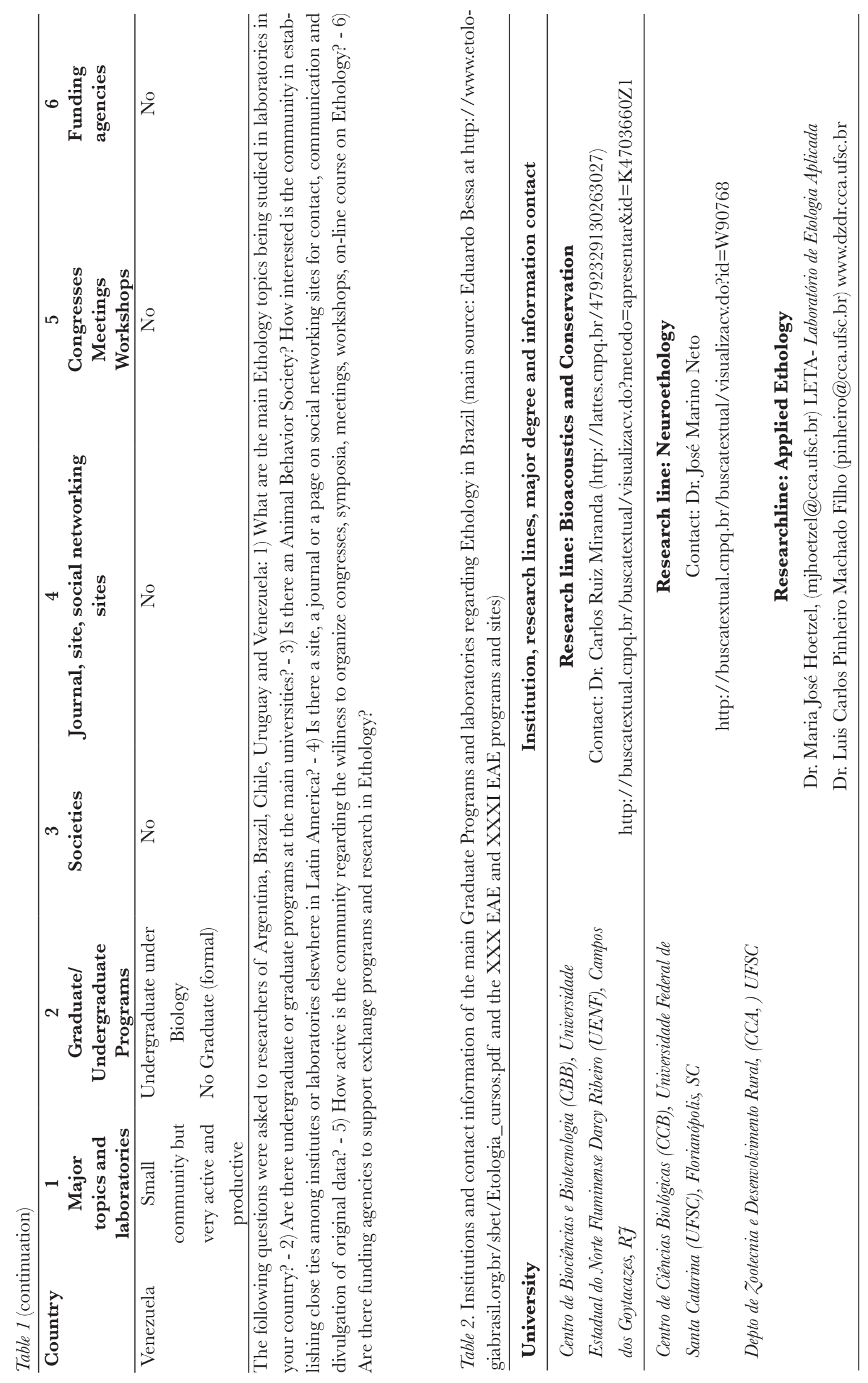


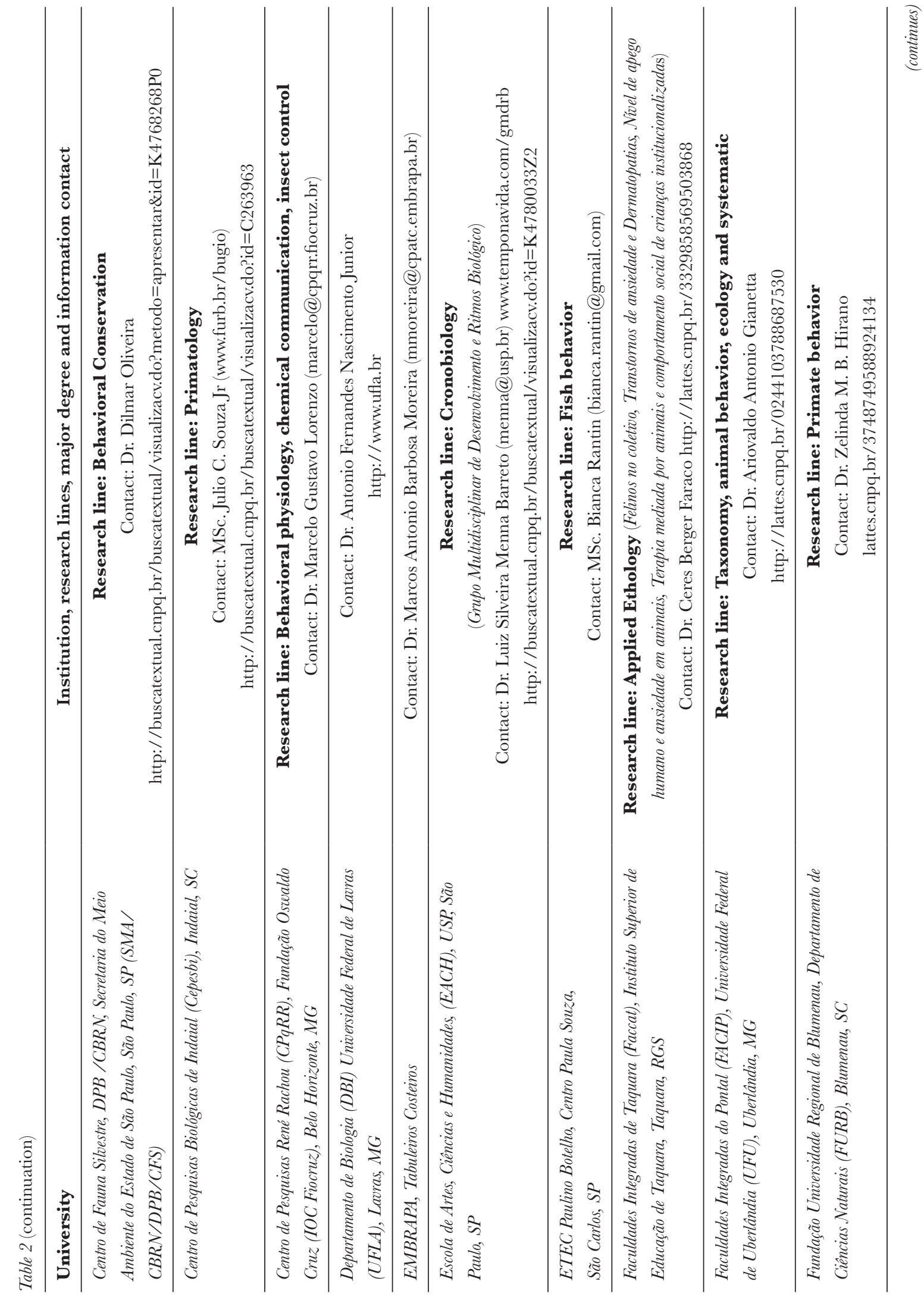




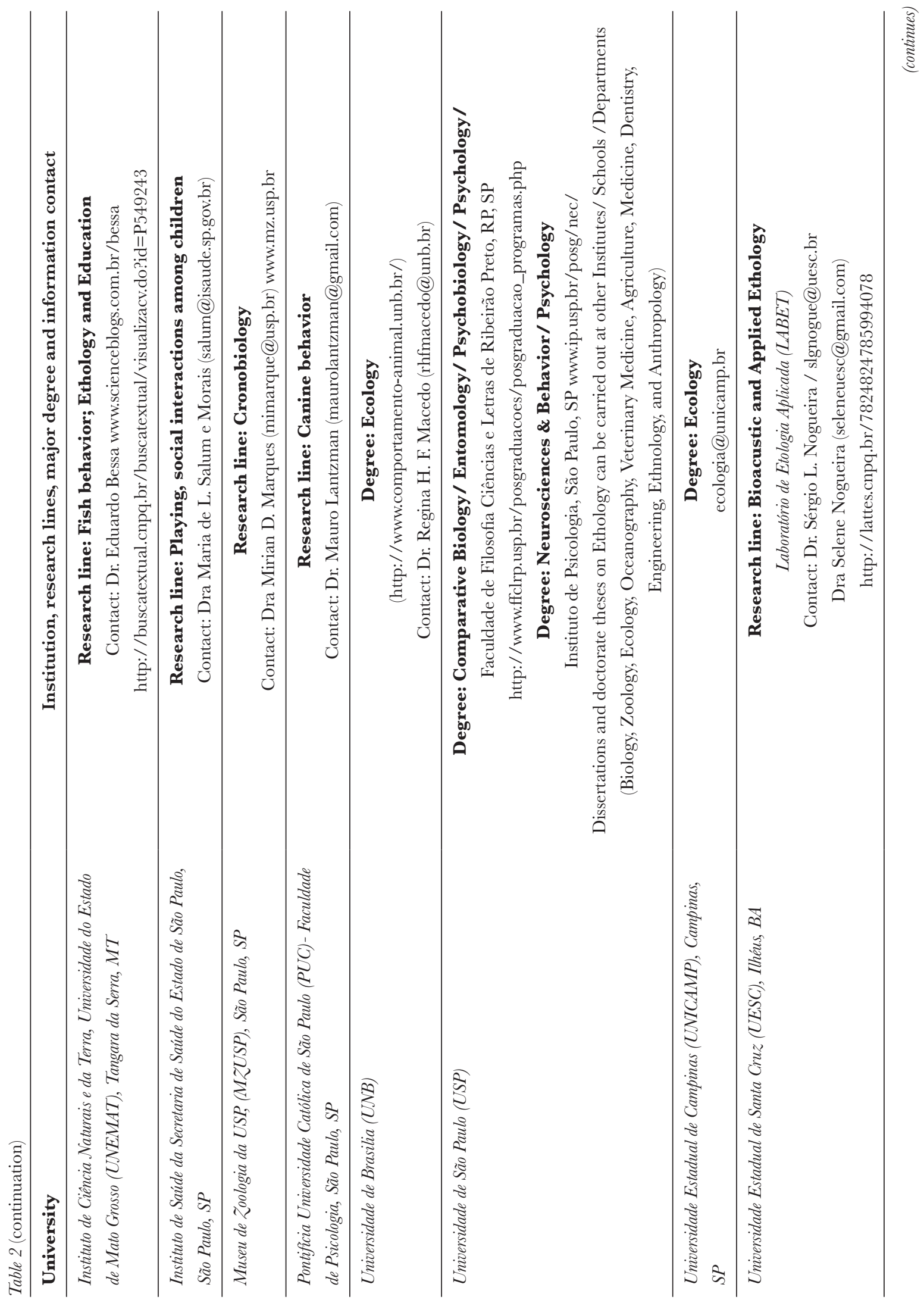


Elisabeth Spinelli de Oliveira et al.

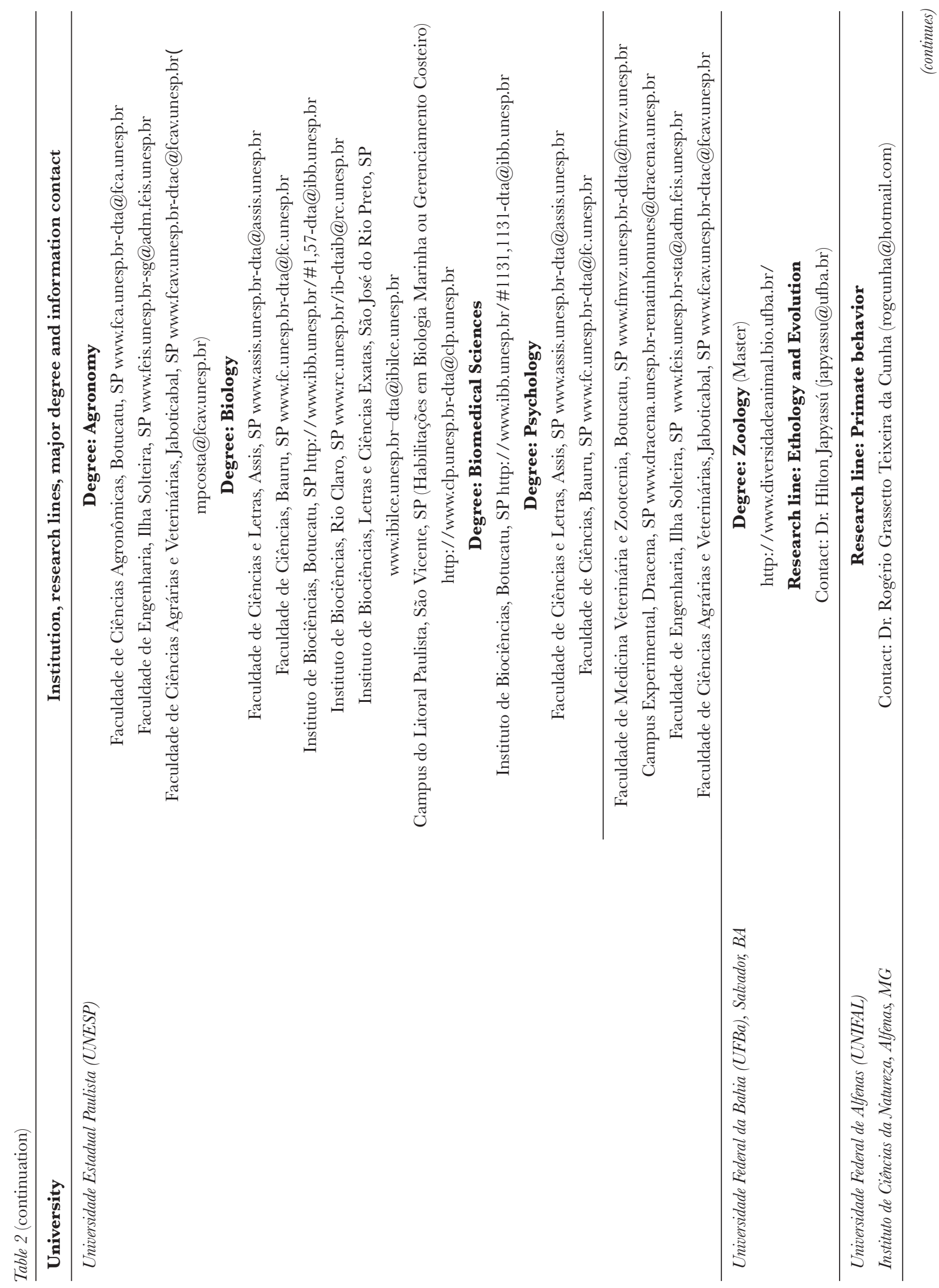




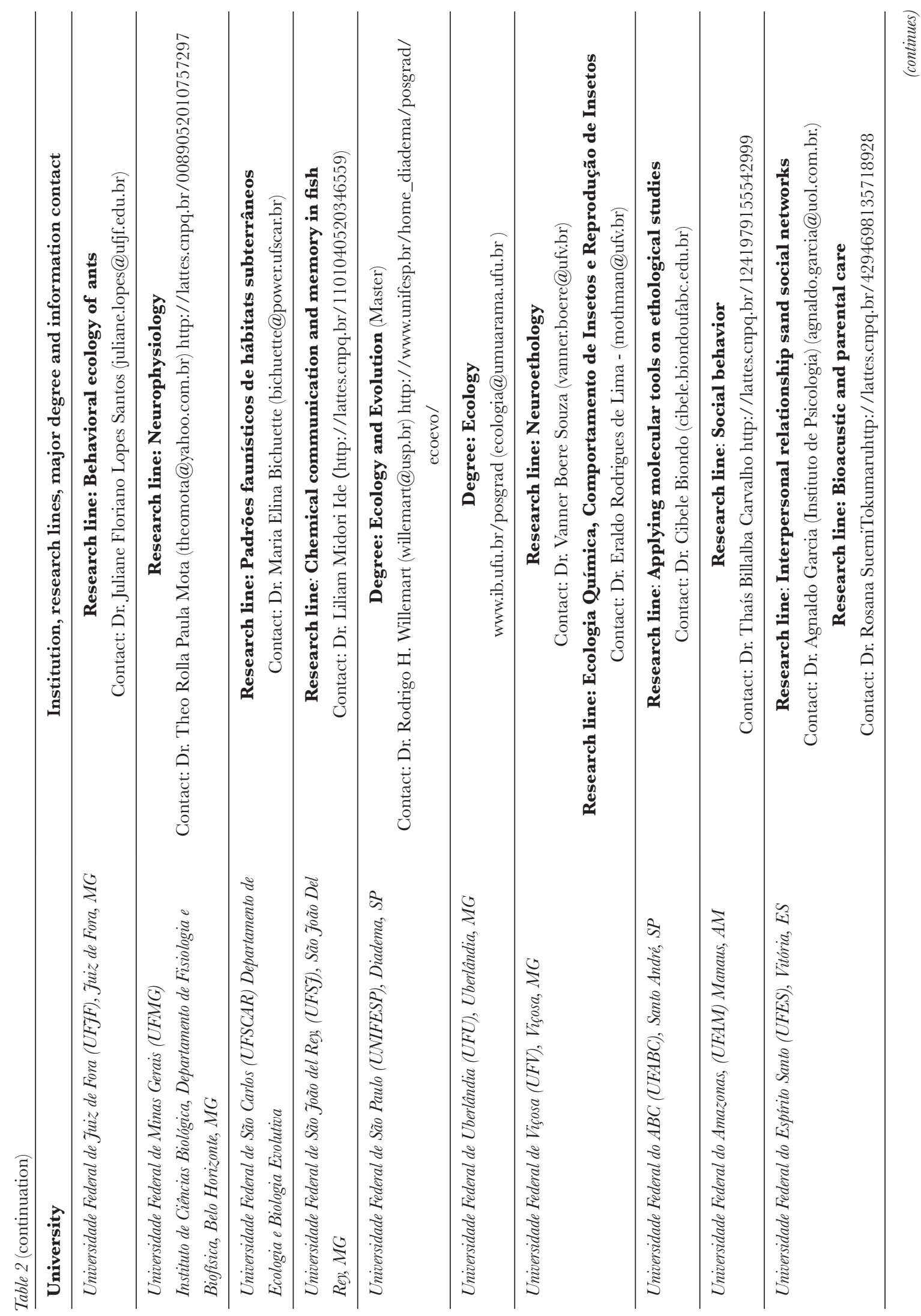




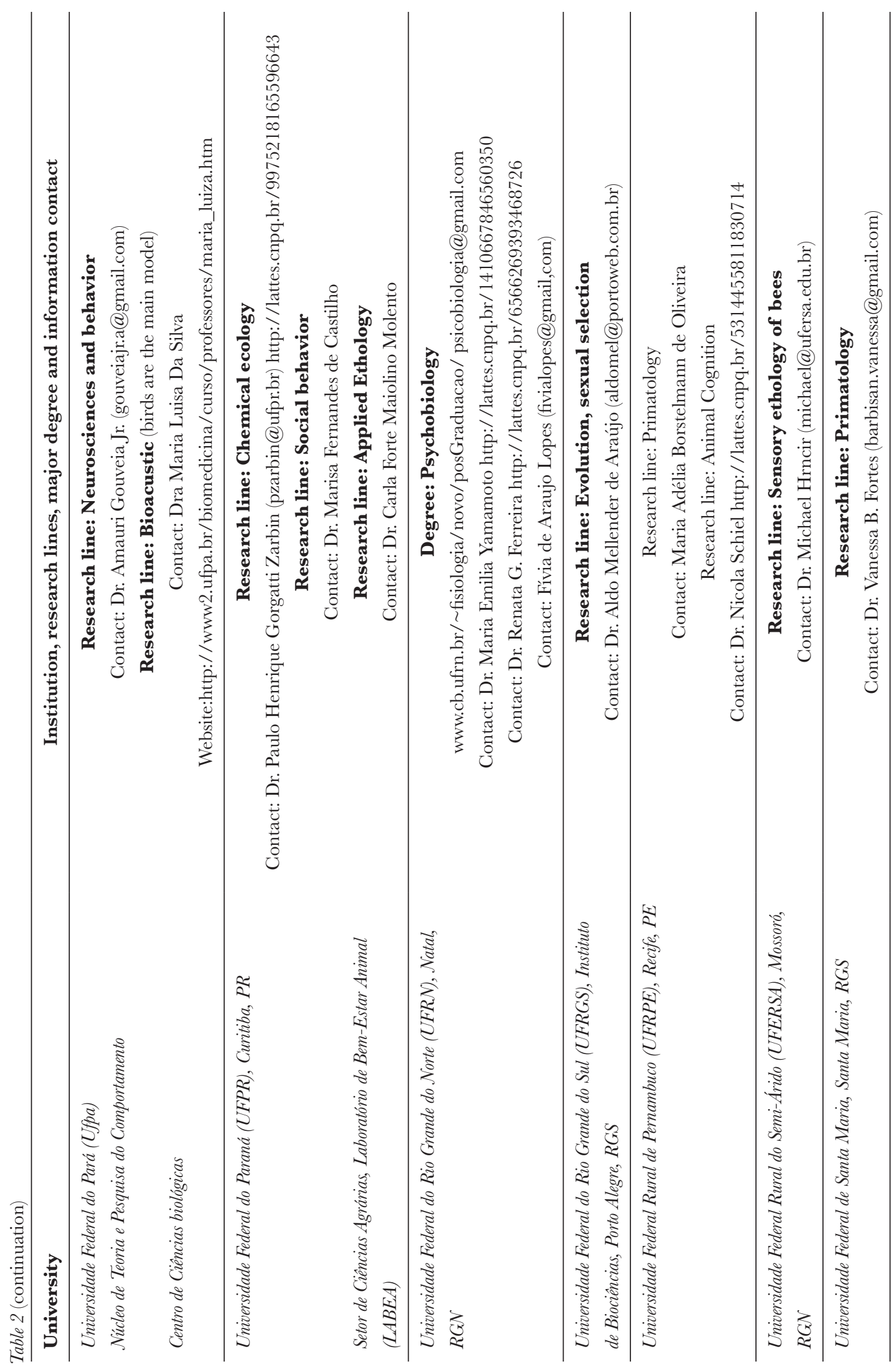


A Glimpse at Ethology in Latin America

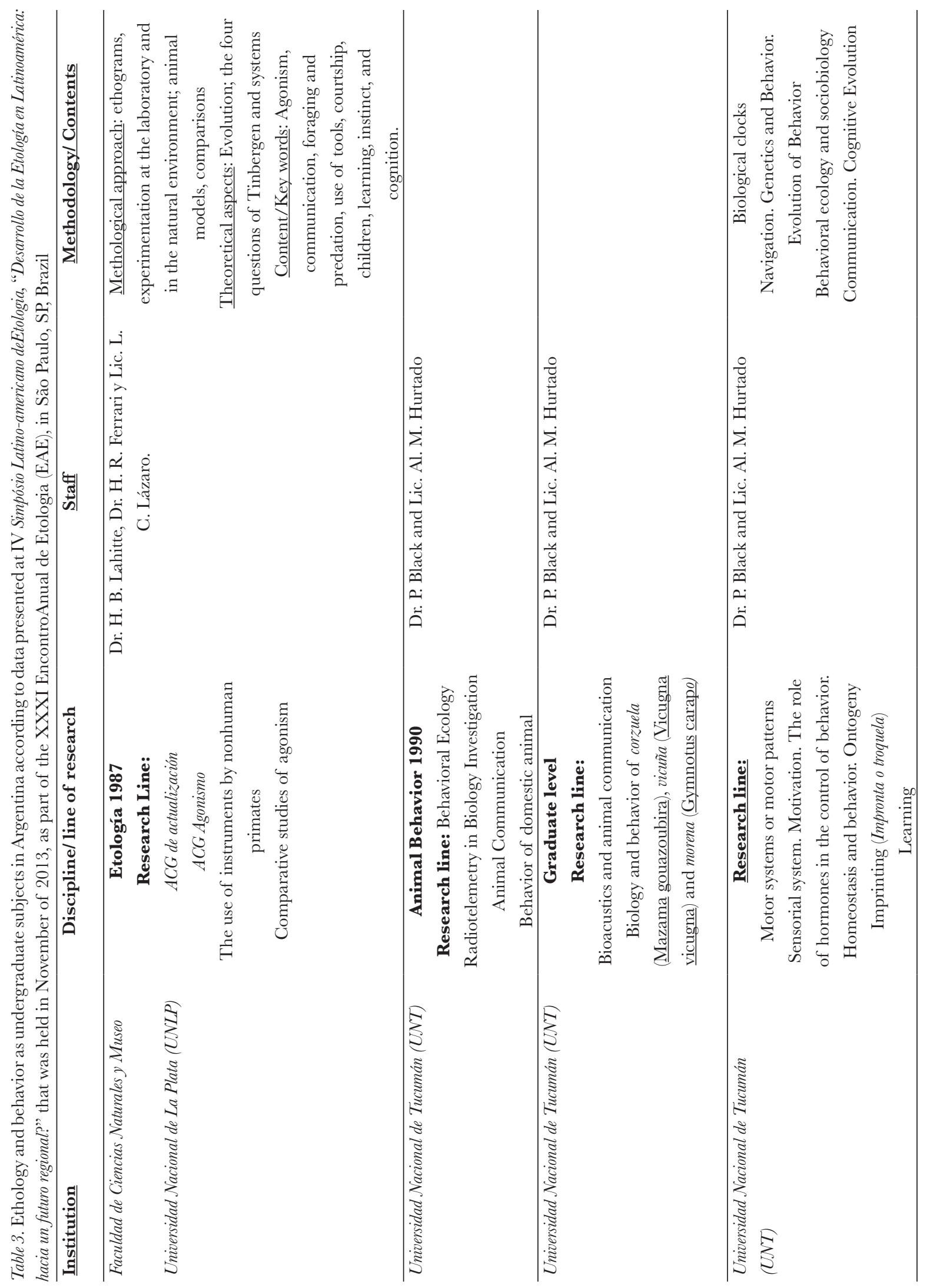




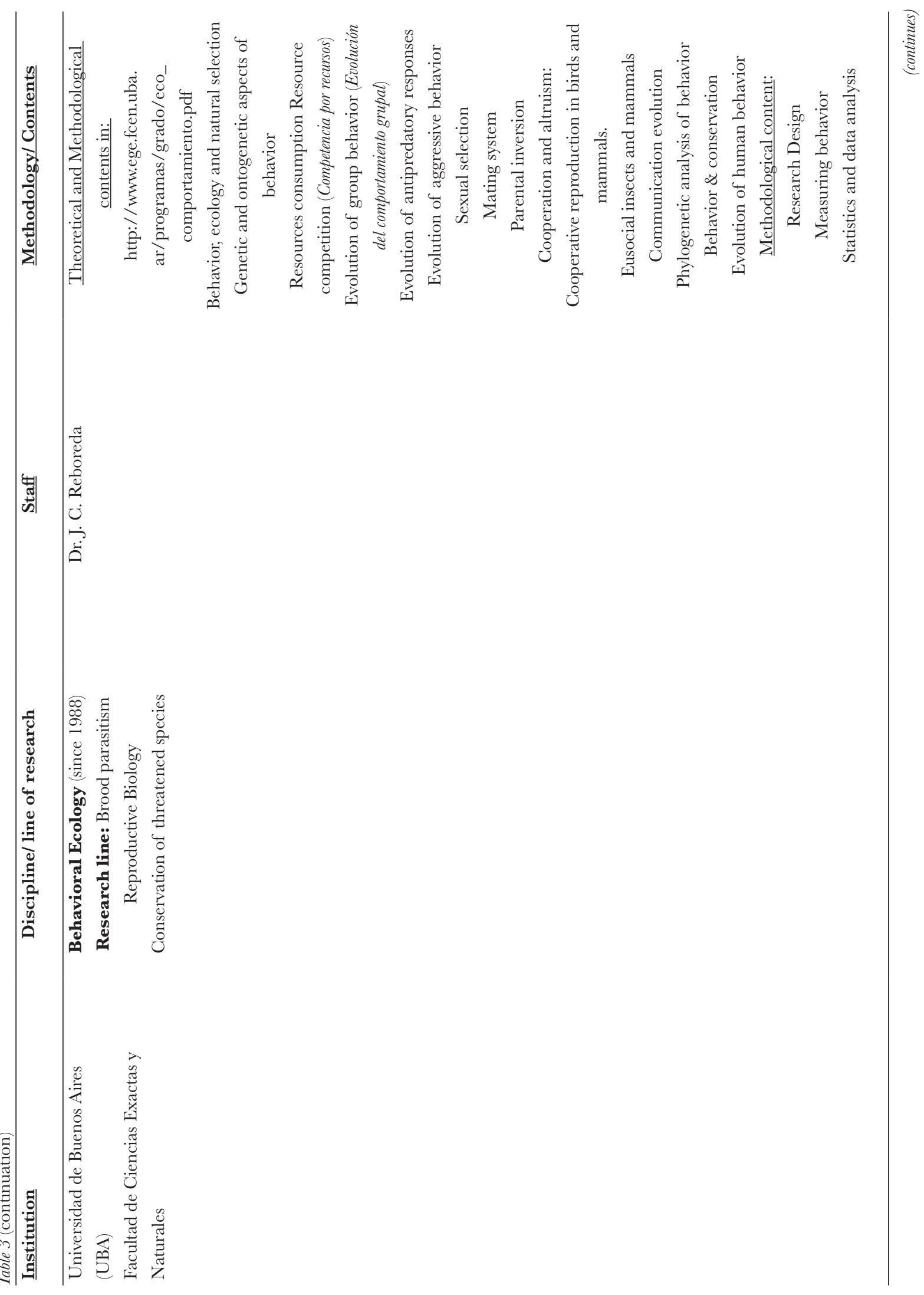


A Glimpse at Ethology in Latin America

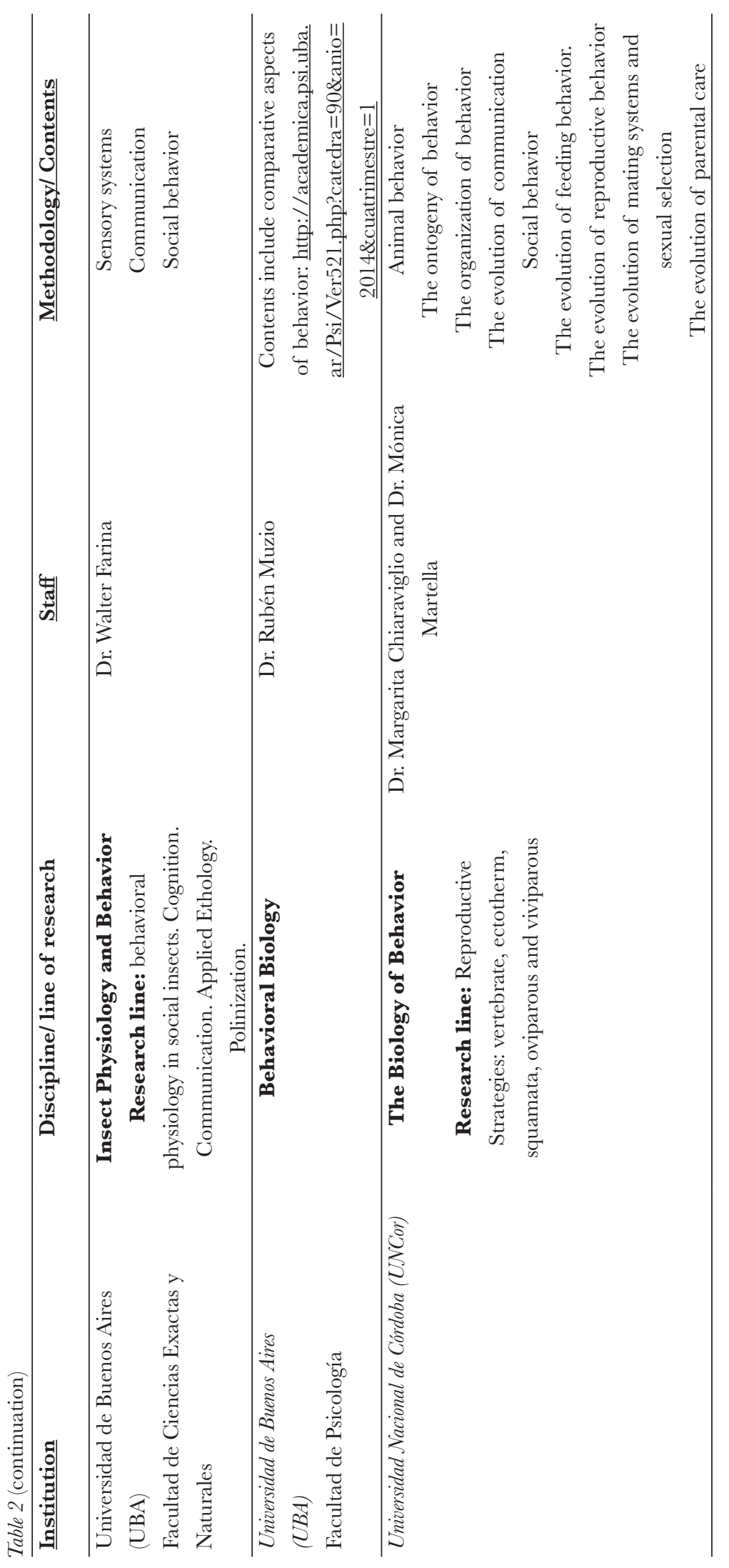


Appendix - List of invited guest from Latin America at the $X X X$ Encontro Anual de Etologia (EAE), III Simpósio Latinoamericano "Etologia na América Latina", and XXXI EAE, IV Simpósio Latinoamericano de Etologia "Desarrollo de la Etología en Latinoamérica: ¿hacia un futuro regional?", both held in Brazil.

\section{ARGENTINA}

\section{Dr. Alfredo V. Peretti \\ Cátedra de Diversidad Animal, Córdoba, Argentina.}

Research line: Estrategias reproductivas en Scorpiones, Solifugae, Opiliones y Pseudoscorpiones (Arachnida) de Argentina: comportamiento sexual y de cría, transferencia espermática y procesos asociados.

http: / / www.efn.uncor.edu/dep/divbioeco / DivAnil/alf/alf.htm

\section{Dr. Ruben Mentzel}

Ciudad Autónoma de Buenos Aires, Buenos Aires, Argentina. Research line: Etología aplicada. Bienestar animal https://ar.linkedin.com/pub/rubén-mentzel

\section{Dr. Daniel Tomsic}

Profesor do Departamento Fisiología, Biología Molecular y Neurociencias, Facultad de Ciencias Exactas y Naturales. Universidad de Buenos Aires.

Research line: Investigacion de neurobiologia de la memoria.

http:/ / www.ifibyne.fcen.uba.ar/new/en/temas-de-investigacion/laboratorio-de-neurobiologia-de-la-memoria-lnm/neuroetologia-y-neurofisiologia/ dr-daniel-tomsic/

\section{Dra. Monique Halloy}

Profesor Adjunto no Instituto de Herpetología de la Fundación Miguel Lillo, Universidade do Tucuman, Argentina.

Research line: Fisiología comportamiental.

h t t p : / / w w w. m g a u n t. com . a r / index . php?option $=$ com_content $\&$ task $=$ view\&id=19\&Ite mid=4

\section{Dr. Hector Ricardo Ferrari}

Cátedra de Etología, Facultad de Ciencias Naturales y Museo, Universidad de Nacional la Plata, La Plata, Argentina.

Research line: Bienestar animal
Dr. Martin Giurfa (giurfa@cict.fr)

Research Center on Animal Cognition, Université Paul Sabatier, Toulouse, França

Research line: Perception, Learning and Memory in Insects (PLMI)

www.neurobiologie.fu-berlin.de/Giurfa.html

Dr. Walter Farina (walter@bg.fcen.uba.ar) Departamento de Biodiversidad y Biología Experimental, Facultad de Ciencias Exactas y Naturales, Universidad de Buenos Aires, Argentina

Research line: Behavioral Physiology, Cognition and Animal Communication in Social Insects.

Dra. Roxana Josens (roxy@bg.fcen.uba.ar ) Facultad de Ciencias Exactas y Naturales, Universidad de Buenos Aires (UBA). IFIBINE-CONICET

Research line: Behavioral Physiology of Ants

GHILE

Dra. Ana María Fernández Tapia (ana. fernandez@usach.cl)

Psicología Universidad de Chile.

Research line: Psicología

Dra. Kathleen Whitlock

University of Valparaiso, Chile (kathleen.whitlock@, un.cl)

Centro Interdisciplinario de Neurociencia de Valparaíso (CINV) Universidad de Valparaíso, Avenida GranBretana 1111, Valparaíso, Chile

Research line: Genetic and development of olfactory system

Dr. L. A. Ebensperger (www.bio.puc.cl/ profs/ebensperger/)

Pontificia Universidade Católica do Chile, Santiago do Chile, Chile.

Research line: Fisiología comportamiental

\section{COLOMBIA}

Dr. Alejandro Rosas (http://www.docentes. unal.edu.co/arosasl/)

Universidad Nacional de Colombia, Bogotá

Research line: Evolución de cooperación, evolutiva ética y psicología moral 
Dra. Paula Catalina Caycedo Rosales

Curadora de la Colección de Sonidos Ambientales

Instituto Alexander von Humbolt da Colômbia, Laboratório de Bioacústica

Research line: Series Colombia Diversidad Biótica; Plan de Conservación para la reinita cerúlea (Setophaga cerulea) en sus sitios de invierno; Bioacústica y monitoreo; Reconocimiento Automatizado de sonidos

\section{MEXICO}

Dr. Gabriel Ramos-Fernandez (http://www. ciidiroaxaca.ipn.mx/)

Instituto Politécnico Nacional (IPN), CIIDIR, Unidade

Oaxaca, Oaxaca, México

Research line: Social Behavior
Dr. Genaro Goria-Avila (http://www.uv.mx/ personal/gcoria/author/gcoria/)

Universidad Veracruzana, México

Research line: Base neural de la conducta sexual y la cría de animales.

\section{VENEZUELA}

\section{Dr. Trino Baptista}

Department of Physiology, Medical School, Los Andes University, P.O. Box 93, Mérida, 5101-A, Venezuela

Research line: Psiquiatria evolucionista 